\title{
“Gönüllülük” kan merkezlerine başvuruda fark yaratır mı? Ankara'da seçilmiş kan merkezleri başvuruları üzerinden bir değerlendirme
}

\author{
Ecem Cantürka, Serdar Ceylanb, Uğur Yasin Akgünc, Ali Yavuz Kululard, Yücehan Kurtuluşe, \\ Abedalazeze Alnawajhaf, Meltem Şengeleng, Dilek Aslan ${ }^{\mathrm{h}}$
}

\section{Özet}

Amaç: Ankara'da bir üniversite hastanesinin kan merkezinde ve Kızllay'a bağlı bazı merkezlerde yapılmış olan bu araştırmanın iki amacı bulunmaktadır. Amaçlardan ilki kan bağışında bulunanların sosyo-demografik özelliklerinin, kan bağışıyla ilgili bilgi ve tutumlarının, onları "gönüllü" olmaya iten motivasyonel sebeplerin belirlenmesidir. İkinci amaç ise bu iki farklı kurumda (üniversite hastanesi ve Kızılay Kan Merkezi) bağış yapan kişiler arasında "gönüllü bağışçılık" açısından fark olup olmadığının belirlenmesidir. Yöntem: Araştırmanın verileri Ankara'da bir üniversite hastanesinin kan merkezi ve Kızılay'a bağlı bazı merkezlerde 01-05 Ekim 2012 tarihleri arasında toplanmıştır. Bu merkezlere başvuran kişilerde; kan bağışında bulunma, çalışmaya katılmayı kabul etme ve sözlü iletişim kurulabilme şartları aranmıştır. Çalışmaya katılmayı kabul eden 277 kişi araştırma anketini cevaplamıştır. Verilerin analizinde SPSS 15.0 paket programı kullanılmıştır. Tanımlayıcı istatistiklere ek olarak Ki kare testi, t testi, Fisher'in kesin testi, Mann Whitney U testi ve ANOVA kullanılmıştır. Bulgular: Katılımcıların \%85.2'si erkektir. Katılımcıların çalışma esnasındaki bağıșta bulunma nedenleri arasında en sık olan akrabalarından/ tanıdıklarından birinin ihtiyacı olmasıdır (\%57.0). Katılımcıların \%80.9'u daha önce en az bir kez kan bağışında bulunmuştur. Gönüllü olarak kan bağışlayanların yüzdesi Kizılay'a bağlı merkezlerde (\%93.0) üniversite hastanesine (\%7.4) göre daha yüksektir. Sonuç: Halka kan bağışının önemi anlatılmalı, halkın kan bağışı konusundaki yanlış inanışları düzeltilmeli ve akıllardaki soru işaretleri giderilmelidir. Halkı kan bağışında bulunmaya teşvik edebilmek için kampanyalar yapılmalı ve sivil toplum örgütlerinin kan bağışı konusuna eğilmeleri sağlanmalıdır.

Anahtar Kelimeler: Kan bağışı, bağış̧̧ı, gönüllü bağışçı

a Dr., Hacettepe Üniversitesi Tıp Fakültesi 2013 yılı mezunu

b Dr., Hacettepe Üniversitesi Tıp Fakültesi 2013 yılı mezunu

c Dr., Hacettepe Üniversitesi Tıp Fakültesi 2013 yılı mezunu

d Dr., Hacettepe Üniversitesi Tıp Fakültesi 2013 yılı mezunu

e Dr., Hacettepe Üniversitesi Tıp Fakültesi 2013 yılı mezunu

f Dr., Hacettepe Üniversitesi Tıp Fakültesi 2013 yılı mezunu

g Öğr. Gör. Dr., Hacettepe Üniversitesi Tıp Fakültesi Halk Sağlığı Anabilim Dalı, Ankara

hProf. Dr., Hacettepe Üniversitesi Tıp Fakültesi Halk Sağlığı Anabilim Dalı, Ankara

Sorumlu Yazar: Meltem Şengelen, Hacettepe Üniversitesi Tıp Fakültesi, Halk Sağlığı Anabilim Dalı, Ankara. Tel: 0312 3051595, E-mail: meltems@hacettepe.edu.tr

Geliş tarihi: 30.11.2012, Kabul tarihi: 20.03.2013 


\title{
Does volunteerism make any difference to admissions to blood centers: An evaluation from admissions to two selected blood centers in Ankara
}

\begin{abstract}
Aim: This study, conducted in Ankara between October 1-5 at a university hospital blood center and in Kizllay blood centers has two aims. The first one was to determine the socio-demographic characteristics of the blood donors, their knowledge and attitudes regarding blood donation and their motivations. The second aim was to determine whether there was a difference in voluntary donations between the two institutions. Materials and Methods: Data were collected between October 1-5 at a university hospital's blood center and two of Kizllay's blood centers in Ankara. Inclusion criteria consisted of blood donation, verbal consent to participate in the study and verbal communication. Two hundred and seventy-seven blood donors agreed to participate in the study and completed the study questionnaire. Statistical analysis was performed by SPSS 16.0. Descriptive analysis, Chi-square test, Fisher's exact test, t test, Mann Whitney U test and ANOVA were used. Results: Eighty-five point two percent of the participants were male. The most common reason for blood donation at the time of the study was the need of a relative/friend (57.0\%). Eighty point nine percent of the participants had donated blood previously. The percentage of those donating blood on a voluntary basis was higher at Kizllay blood centers $(93.0 \%)$ than at the university hospital $(7.4 \%)$. Conclusion: The importance of blood donation should be promoted and the wrong beliefs among the community about blood donation should be corrected. Campaigns encouraging people to donate blood should be organized and non-governmental organizations should be provided to deal with blood donation.
\end{abstract}

Key words: Blood Donation, Blood Donor, Voluntary Blood Donor

\section{Giriş}

$\begin{array}{cccc}\text { Kan } & \text { bağışçısı, tam kan ya da } \\ \text { beren } & \text { kişsi } & \text { olarak }\end{array}$ tanımlanmaktadır. ${ }^{1}$ Kan bağış̧̧ıları, Dünya Sağlık Örgütü (DSÖ) tarafından, gönüllü ve karşılıksız kan bağışçıları, akraba/tanıdık için bağışta bulunanlar (kana kan bağış̧̧ısı) ya da replasman (hastane stoğunu yerine koyma) bağış yöntemini kullananlar ve para veya paraya dönüşebilecek değerler karşılığı bağıșta bulunanlar olarak tanımlanmıştır. ${ }^{2}$ Ülkemizde en yaygın kan bağışçı grubunu hastanın birinci dereceden akrabaları, yakın dostları ya da iş arkadașları olușturmaktadır.3,4 $\mathrm{Bu}$ grup genellikle gerekli kan bulunamaz ise hastanın durumunun daha da kötüye gideceği, hayati tehlike yaşayacağı endişesi ve bu durumun yarattığı toplum baskısı nedeniyle bağıșta bulunur. Bağış tipi fark etmeksizin, ilk bağışta iyi planlanmış bir yaklaşım gösterilmesi, düzenli ve gönüllü bağışçı kazanımı için son derece önemlidir. ${ }^{3}$ Para ya da maddi çıkar karşılığı bağıș yapanlar en riskli bağışçı grubunu olușturur. ${ }^{3}$

Gönüllü bağışçl; herhangi bir çıkar karşılığı olmadan, tamamen kendi isteğiyle kendi plazma ve hücresel kan bileșenini bağışlayan kişidir. ${ }^{3}$ Kan ve Kan Ürünleri Kanunu'na göre (5624 Sayılı Kanun, madde $3 /$ b) "Kan, kan bileșenleri ve ürünlerinin temininde karşılıksız ve gönüllü bağış esastır". $3 \mathrm{Bu}$ anlamda gönüllü bağışçılar dışında (kana kan/replasman bağışçısı ya da para karşıllğı) bağışta bulunan kişilere kan vericileri demek daha doğru olur. Gönüllük temelinde, para karşılığı olmadan yapılan 
kan bağışı, kişilerin iyi niyetli tutum ve davranışlarının bir sonucudur. Kişilerin diğer insanlara yardımcı olma duygusunun dişa vurum şekillerinden biridir. Bir başka bakış açısıyla da kişinin yaptığı "fedakarlık" olarak değerlendirilebilir. ${ }^{5}$ Bağıșçı seçilirken uygun yaş sınırları içinde ve enfeksiyon ya da ciddi bir hastalığı olmayan gönüllülerden kan alınması tüm dünyada kabul görmüş genel bir kuraldır. ${ }^{6}$

Gönüllü ve güvenilir kan bağışçısı kazanımı için İkinci Dünya Savaşından sonra modern kan bankacılığı yaklaşımına gerek duyulmuştur. Dünya ülkeleri kendi sosyoekonomik ve coğrafi koşullarına uygun olarak, yeniden yapılanma sürecinde yerel ya da hastane bünyesindeki kan merkezleri yerine, bölgesel kan merkezleri ya da karma sistem uygulamalarını önermişlerdir. ${ }^{3}$ Gönüllü kan bağışçısı kazanımı tüm dünyada zor olmaktadır ve bu amaçla profesyonel çalışanların yer aldığı özel kan hizmet birimleri oluşturulmuştur. Bu alanda çalışan kuruluşları Kızılay/Kızılhaç Dernekleri, Hastane ve üniversite kan merkezleri, Sivil toplum örgütleri şeklinde üç grupta toplamak mümkündür. ${ }^{3}$

Bir ülkede; ihtiyacı olan hastaların transfüzyon tedavisi için, yeterli ve güvenli kan ve kan bileşeninin temin edilmesi önemli ve öncelikli bir sağlık hizmetidir. Ülkemizde bu kapsamdaki tüm hizmetlerin planlanması, yürütülmesi ve denetlenmesinden Sağlık Bakanlığı yetkili ve sorumludur. ${ }^{3}$ Ülkemiz kan bağışı yönünden gelişmiş ülkelerin gerisindedir.

Amerika Birleşik Devletleri (ABD), Almanya, Kanada, Japonya gibi gelişmiş ülkelerde kan bağışlayanların toplam nüfus içindeki payı \%5 iken ülkemizde bu değerin \%1-2 civarında olduğu ifade edilmektedir. Ayrıca gelişmiş ülkelerde kan ihtiyacının yaklaşık \%80'i gönüllü bağışçılarından elde edilirken Türkiye'de bu rakam çok daha azdır. Ancak günümüzde yapılan çalışmalarla bu değer artırılmaya çalışılmaktadır. ${ }^{3}$ Bununla birlikte 2006 yılında ülkemizde tahmin edilen kan ihtiyacı yaklaşılk olarak 1.5 milyon ünite olarak ifade edilmiştir. ${ }^{7}$ Günümüzde bu gereksinimin artmış olması muhtemeldir.

$\mathrm{Bu}$ araștırmanın iki amacı bulunmaktadır. Amaçlardan ilki kan bağışında bulunanların sosyo-demografik özelliklerinin, kan bağışıyla ilgili bilgi ve tutumlarının, onları "gönüllü" olmaya iten motivasyonel sebeplerin belirlenmesidir. İkinci amaç ise birisi üniversite hastanesi olmak üzere iki farklı kurumda (üniversite hastanesi ve Kızılay Kan Merkezi) bağış yapan kişiler arasında "gönüllü bağışçılık" açısından fark olup olmadığının belirlenmesidir.

\section{Yöntem}

\section{Araştırmanın yeri ve zamanı}

Araştırma, Ankara'da bir üniversite hastanesinin kan merkezi ve Kızllay Ankara Kan Bağışı Merkezi ve Kızılay Karanfil Sokak Kan Alma Biriminde 01-05 Ekim 2012 tarihleri arasında yapılmıștır.

Tanımlayıcl tipte planlanan bu çalışmanın araştırma grubunu yukarıdaki merkezlere 01-05 Ekim 2012 tarihleri arasında başvuran 18-65 yaş arası kan bağıșçıları oluşturmaktadır. Araştırma için örneklem seçilmemiştir. Araştırmanın yapıldığ tarihlerde merkezlere başvuran bütün gönüllüler çalışma kapsamına alınmıştır. Araştırmaya toplam 277 kişi katılmıştır. Katılımcıların 162'si (\%58.5) üniversite hastanesinin kan merkezinde, 77'si (\%27.8) Kızllay'a bağlı birinci merkezde ve 38'i (\%13.7) ikinci birimde bağıșta bulunmuştur.

\section{Araştırmaya dahil edilme kriterleri}

Araştırmada seçim kriterleri olarak "kan bağışında bulunma, çalışmaya katılmayı kabul etme ve sözlü olarak iletişim kurulabilmiş olması" belirlenmiştir. 


\section{Araştırmada kullanılan tanımlar ${ }^{1,7}$}

Kan bağışı merkezi: Bağışçıdan kan alan, işleyiş yönünden bölge kan merkezine bağlı olarak çalışan birim

Replasman kan bağışçısı: Kana kan, yerine koyma, zorunlu kan bağışı, aile kan bağışçıları yöntemi olarak tanımlanır.

Gönüllü kan bağışçısı: Herhangi bir çıkar karşılığı olmadan, tamamen kendi isteğiyle kendi plazma ve hücresel kan bileşenini bağışlayan kişidir. ${ }^{3}$

Araştırmada kullanılan "gönüllü olma kriteri" şu anda bağışta bulunma nedeninin akraba/arkadaş ihtiyacı (kana kan bağışçısı) olarak belirtilmesi ya da belirtilmemesi şeklinde tanımlanmıştır. Akrabalarından /tanıdıklarından birinin ihtiyacı olması nedeniyle kan bağışlayanlar ayrı tutularak geriye kalan bağışçılar gönüllü olarak kabul edilmiștir.

\section{Araştırmanın ön denemesi}

Kızılay Kan Merkezleri'ne 21 Eylül 2012 tarihinde kan bağışlayan 18 gönüllü arasında ön deneme yapılmıştır. Ön deneme sonucunda görülen eksiklikler giderilerek 28 Eylül 2012'de veri toplama formuna son şekli verilmiştir.

Araștırmanın verileri yüz yüze görüşme tekniği kullanılarak toplanmıştır.

\section{Verilerin analizi}

Verilerin analizinde SPSS 15.0 paket programı kullanılmıştır. Tanımlayıcı istatistikler ve ayrıca Ki kare testi, Fisher'in kesin testi, $\mathrm{t}$ testi, Mann-Whitney $\mathrm{U}$ testi ve ANOVA kullanılmıştır. İstatistiksel anlamlılık sınırı için p değeri 0.05 olarak kabul edilmiştir.

\section{Etik konular}

- Katılımcılara isimleri sorulmamıştır.
- Katılımcllara araştırma ile ilgili sözlü bilgi verilmiştir.

- Araştırmanın yapıldığı kan merkezlerinden yazılı izin alınmıştır.

- Araştırmanın yapılabilmesi için üniversite Etik Kurul'undan izin alınmıştır.

- Araştırmanın verileri ve sonuçları bilimsel amaç dişında kullanılmamıştır.

- Araştırma ayrıntılı raporu ilgili kurum yöneticilerine sunulmuştur.

\section{Bulgular}

Araştırmaya katılanların 236'sı (\%85.2) erkek ve 41'i (\%14.8) kadındır. En fazla katılımcının olduğu yaş grubu 26-45 yaş grubudur (\%57.4; $\mathrm{n}=159)$. En az katılımcının olduğu yaş grubu ise 45 yaş üzeri (\%12.6; $n=35)$ yaş grubudur. Araştırmaya katılanların öğrenim durumuna bakıldığında, 131'inin (\%47.3) üniversite mezunu olduğu, 23'ünün (\%8.3) ilkokul mezunu olduğu görülmektedir.

Katılımcıların \%59.2'si evli (n=164) olduğunu, 18'i (\%6.5) sosyal güvencesi bulunmadığını ve \%69.3'ü herhangi bir işte çalıştığını belirtmiştir. Katılımcıların \%46.2'si çocuk sahibi değilken (n=128), \%41.5'inin bir ve iki çocuğu bulunmaktadır $(\mathrm{n}=115)$ (Tablo 1).

Katılımcların \%80.9'u daha önce en az bir kez kan bağışında bulunmuştur. Katılımcıların araştırma sırasındaki kan bağıșlama nedenlerine bakıldığında üniversite hastanesi kan merkezindeki bağışçların 150'si (\%92.6) akrabalarından/tanıdıklarından birinin ihtiyacı olması nedeniyle kan bağışlamakta, Kızılay kan bağışı merkezlerindeki katılımcların ise 56'sı (\%48.7) sağlı̆ açısından olumlu etkileri olduğu, alışkanlık haline gelmesi gibi farklı nedenlerle kan bağışlamaktadır. Kan bağışlama nedenleri 
arasında bağış merkezine göre anlamlı farklılıklar vardır (Tablo 2).

Üniversite hastanesinde \%98.8, Kızılay kan bağıșı merkezlerinde \%95.7 olmak üzere iki kan merkezinde de yüksek sıklıkta kan bağışında gönüllülüğün önemli olduğu belirtilmiştir $\left(\chi^{2}=2.7, p=0.1\right)$. Kızılay kan merkezlerinde bağıșta bulunanlar büyük ölçüde (\%93.0) gönüllü olarak bağışta bulunurken, üniversite hastanesi kan merkezinde bağışta bulunanlarda bu oran \%7.4'tür $\left(\chi^{2}=201.3, \mathrm{p}<0.001\right)$.

Tablo 1. Kan bağışlayanların bazı sosyodemografik özellikleri (Kan merkezleri, Ankara, 2012)

\begin{tabular}{lcc}
\hline Özellik & Sayı & Yüzde \\
\hline Cinsiyet & & \\
Erkek & 236 & 85.2 \\
Kadın & 41 & 14.8 \\
Yaş & & \\
$18-25$ & 83 & 30.0 \\
$26-45$ & 159 & 57.4 \\
$>45$ & 35 & 12.6 \\
Öğrenim durumu & & \\
İlkokul & 23 & 8.3 \\
Ortaokul & 35 & 12.6 \\
Lise & 88 & 31.8 \\
Yüksek & 131 & 47.3 \\
lisans/Üniversite & & \\
Medeni durum & & \\
Evli & 164 & 59.2 \\
Evli değil & 113 & 40.8 \\
Sosyal güvence & & \\
SGK & 259 & 93.5 \\
Yok & 18 & 6.5 \\
Çalışma durumu & & \\
Çalışıor \\
Çalışmıyor & 192 & 69.3 \\
& 85 & 30.7 \\
Çocuk sayısı & & \\
Yok & & \\
1-2 & 128 & 46.2 \\
3 ve üzeri & 115 & 41.5 \\
& 34 & 12.3 \\
\hline Toplam & & \\
\hline
\end{tabular}

Araştırmada gönüllü olarak bağışta bulunanlar ve akraba/tanıdıklarının ihtiyacı nedeniyle kan bağışlayanlar arasında cinsiyet, yaş, öğrenim durumu, medeni durum, çalışma durumu ve çocuk sayısı bakımından istatistiksel olarak anlamlı fark bulunmaktadır (Tablo 3).

Gönüllü olarak bağıșta bulunanların \%22.7'si, replasman kan bağışçllarının \%8.9'u kadındır. Gönüllü olarak bağıșta bulunanların \%44.5'i 18-25 arası yaș grubunda, replasman kan bağışçlarının ise \%72.2'si 26-45 yaș grubundadır. Katılımcıların genel olarak öğrenim seviyesi arttıkça kan bağışlama yüzdesi artmaktadır. Gönüllü olarak bağışta bulunanların \%60.5'i, replasman kan bağışçılarının \%37.3'ü üniversite/yüksek lisans öğrenimi almıştır. Gönüllü olarak bağıșta bulunanların \%38.7'si, replasman kan bağışçılarının ise \%74.7'si evlidir. Gönüllü olarak bağıșta bulunanların \%48.7'si, replasman kan bağışçılarının ise \%84.8'i çalışmaktadır (Tablo 3).

Üniversite hastanesinde kan bağıșlayan katılımcıların büyük bir çoğunluğu (\%82.5) daha önce hastanede, Kızılay'da kan bağıșlayanların büyük çoğunluğu (\%80.9) da daha önce Kızılay kan bağışı merkezlerinde bağıșta bulunmuşlardır. Katılımcıların neredeyse tamamı (\%97.1) "tekrar kan bağışında bulunur musunuz?" sorusuna "evet" cevabını vermiștir.

\section{Tartışma}

Araştırmaya katılanların 236'sı (\%85.2) erkek, 41'i (\%14.8) kadındır. Daha önce yapılmış çalışmalarda farklı sonuçlar olmakla beraber Türkiye genelinde kan bağışlayanların büyük kısmı erkektir. Kızılay kan hizmetlerinin 2011 verilerinde kan bağışlayanların \%94'ü erkek iken, bu değer yapılan çalışmada tüm katılımcılar arasında \%85.2, Kızılay kan merkezlerine bağışta bulunanlar arasında \%77.4'dür. ${ }^{8}$ 
Yurtdışında yapılan çalışmalarda da benzer sonuçlar yer almaktadır.

Yurtdışında yapılan bir çalışmada kadınların daha az bağışta bulunmaların nedeni; bağış sonrası kansız kalmaktan korkmaları ve bașvuranların üçte birinin düşük hemoglobin $(\mathrm{Hb})$ seviyesi nedeni ile reddedilmesi olarak açlklanmıştır. ${ }^{11}$ New York Kan Merkezi'nde yapılan bir çalışmada düşük $\mathrm{Hb}$ seviyesi nedeniyle bağışta bulunamayanların yüzde 93'ünü kadınların oluşturduğu belirtilmiştir. ${ }^{9}$

$$
\text { Medikal engellerin ortadan }
$$
kaldırılması ve rutin kontroller ile kadın bağıșçı sayısının artışının mümkün olduğu çeşitli çalışmalarda gösterilmiştir. ${ }^{9}$ Kadın bağışçılara ret nedeninin doğru aktarılması, tedavi sonrası bağışta bulunmalarında bir sakınca olmadığının belirtilmesi ve kan bağışı için teşvik edilmesinin; bağışçı sayısının artışında önemli bir yere sahip olduğu görülmüştür.

Tablo 2. Kan bağışlayanların araştırma sırasındaki kan bağışlama nedenlerinin dağılımı (Kan Merkezleri, Ankara, 2012)

\begin{tabular}{|c|c|c|c|c|c|c|}
\hline \multirow{3}{*}{ Kan bağışlama nedeni } & \multicolumn{4}{|c|}{ Kan merkezi } & & \\
\hline & \multicolumn{2}{|c|}{ Üniversite } & \multicolumn{2}{|c|}{ Kızılay } & \multicolumn{2}{|c|}{ Toplam } \\
\hline & Sayı & Yüzde* & Sayı & Yüzde* & Sayı & Yüzde* \\
\hline $\begin{array}{l}\text { Akrabalarından/tanıdıklarından birinin } \\
\text { ihtiyacı olması }\end{array}$ & 150 & 92.6 & 8 & 7.0 & 158 & 57.0 \\
\hline $\begin{array}{l}\text { Sağlığı açısından olumlu etkileri olması, } \\
\text { alışkanlık haline gelmesi }\end{array}$ & 5 & 3.1 & 56 & 48.7 & 61 & 22.7 \\
\hline $\begin{array}{l}\text { Sivil toplum } \quad \text { örgütlerinin } \\
\text { tanıtımı/kampanyaları, görev olduğu için }\end{array}$ & 2 & 1.2 & 21 & 18.3 & 23 & 8.3 \\
\hline $\begin{array}{l}\text { Daha önce kendi ihtiyacı olması, yeni } \\
\text { insanlar tanıma, kendisini önemli } \\
\text { hissetme, eşinin/arkadaşlarının önemli } \\
\text { olduğunu düşünmesi, bulaşıcı hastalıklar } \\
\text { için test yaptırma olanağ }\end{array}$ & 5 & 3.1 & 30 & 26.0 & 35 & 11.9 \\
\hline Toplam & 162 & 100.0 & 115 & 100.0 & 277 & 100.0 \\
\hline
\end{tabular}

*Sütun yüzdesidir. $\left(\chi^{2}=2.0, p<0.001\right)$

Çalışmada yaş dağılımına bakıldığında 18-25 yaş arası genç nüfus; bağışta bulunanların \%30'unu oluşturup, Kızllay kan hizmetleri 2011 verileri yaş dağılımı ile benzerlik göstermektedir. ${ }^{8}$ Genç kan bağışçısı sayısının fazla olması kan stoku ve devamlılık açısından önemlidir. Ülkemizde toplam nüfusun yarısını 30 yaş altı grubun oluşturduğu göz önüne alındığında genç nüfusun kan bağışına katkısı ve katılımın arttırılması önemlidir.

Dünya Sağllk Örgütü verilerine göre düşük gelir düzeyindeki ülkelerde genç yaş grubundaki bireylerin, orta yaş grubu bireylere göre daha fazla kan bağışında bulunduğu belirtilmektedir. $^{2}$

Çalıșmada bağıșta bulunanların yaş ortalaması 32.8'dir. Daha önce yapılmış bazı çalışmalarda yaş ortalaması daha düsük, bazılarında ise benzer bulunmuştur. 10,12,13 $^{2}$

Kan bağışı davranışında bireylerin öğrenim durumunun; bağışta bulunanların kan bağışının önemini kavramaları, toplumda farkındalığın artırılmasını sağlamaları, gönüllü olmayan kan bağıșı ve 
riskli kan bağışının önüne geçilmesini sağlaması açısından önemli olduğu düşünülmüştür. Öğrenim durumunun kan bağışı davranışı üzerine etkisi daha önce ülkemizde yapılan çalışmalarda da gösterilmiştir. Kayseri'de 2010 yılında yapılan bir çalışmada üniversite öğrencileri ile şehir merkezinde yaşayan insanların kan bağışı konusundaki isteklilikleri karşılaştırılmıștır. Araştırmaya katılan diğer bireylerin \%95'inin eğitim seviyesi lise mezunu veya daha düşük düzeydedir. Kan bağışı konusunda bilgilendirilen üniversite öğrencilerinin \%66'sı kan bağışı için başvurmuşken, bu değer araştırmaya katılan diğer bireylerde $\% 29$ 'da kalmıștır. Üniversite öğrencileri bir yıl içinde daha fazla başvuruda bulunmuş; SMS, e-posta vb. yöntemlerle hatırlatma yapıldığında geri dönüș değerleri daha yüksek olmuștur. ${ }^{14} \mathrm{Bu}$ amaçla katılımcıların öğrenim durumları değerlendirildiğinde; 131 kişinin (\%47.3) üniversite/yüksek lisans, 88'inin (\%31.8) lise, 58'inin (\%20.9) ise ilkokul veya ortaokul seviyesinde öğrenim gördükleri saptanmıștır. 2011 yll Kızılay kan hizmetleri verilerinde öğrenim seviyelerine göre bağışçı dağılımı ise üniversite/yüksek lisans \%36, lise \%32, ilk ve orta öğrenim \%32 şeklindedir. ${ }^{8} \quad \mathrm{Bu}$ iki veri karşılaştırıldığında, en fazla bağış yapan kesimin yine üniversite/yüksek lisans öğrenimi görenler olduğu görülmektedir.

Tablo 3. Kan bağışlayanların sosyo-demografik bazı özelliklerinin gönüllü olma durumu ile ilişkisi (Kan merkezleri, Ankara, 2012)

\begin{tabular}{|c|c|c|c|c|c|c|c|c|}
\hline \multirow[b]{3}{*}{ Özellik } & \multicolumn{4}{|c|}{ Gönüllü olma } & \multirow{2}{*}{\multicolumn{2}{|c|}{ Toplam }} & \multirow[b]{3}{*}{$\chi^{2}$} & \multirow[b]{3}{*}{$\mathrm{p}$} \\
\hline & \multicolumn{2}{|c|}{ Evet } & \multicolumn{2}{|c|}{ Hayır } & & & & \\
\hline & Sayı & Yüzde & Sayı & Yüzde & Sayı & Yüzde* & & \\
\hline \multicolumn{9}{|l|}{ Cinsiyet } \\
\hline Erkek & 92 & 77.3 & 144 & 91.1 & 236 & 85.2 & & \\
\hline Kadın & 27 & 22.7 & 14 & 8.9 & 41 & 14.8 & 10.3 & 0.001 \\
\hline \multicolumn{9}{|l|}{ Yaş } \\
\hline $18-25$ & 53 & 44.5 & 30 & 19.0 & 83 & 30.0 & & \\
\hline $26-45$ & 45 & 37.8 & 114 & 72.1 & 159 & 57.4 & & \\
\hline$>45$ & 21 & 17.6 & 14 & 8.9 & 35 & 12.6 & 32.9 & $<0.001$ \\
\hline \multicolumn{9}{|l|}{ Öğrenim durumu } \\
\hline İlkokul & 7 & 5.9 & 16 & 10.1 & 23 & 8.3 & & \\
\hline Ortaokul & 9 & 7.6 & 26 & 16.5 & 35 & 12.6 & & \\
\hline Lise & 31 & 26.1 & 57 & 36.1 & 88 & 31.8 & & \\
\hline Yüksek lisans/Üniversite & 72 & 60.5 & 59 & 37.3 & 131 & 47.3 & 15.6 & 0.001 \\
\hline \multicolumn{9}{|l|}{ Medeni durum } \\
\hline Evli Değil & 73 & 61.3 & 40 & 25.3 & 113 & 40.8 & & \\
\hline Evli & 46 & 38.7 & 118 & 74.7 & 164 & 59.2 & 36.5 & $<0.001$ \\
\hline \multicolumn{9}{|l|}{ Çalıșma durumu } \\
\hline Çalışmiyor & 61 & 51.3 & 24 & 15.2 & 85 & 30.7 & & \\
\hline Çalışıyor & 58 & 48.7 & 134 & 84.8 & 192 & 69.3 & 41.5 & $<0.001$ \\
\hline \multicolumn{9}{|l|}{ Çocuk sayısı } \\
\hline Yok & 76 & 63.9 & 52 & 32.9 & 128 & 46.2 & & \\
\hline $1-2$ & 30 & 25.2 & 85 & 53.8 & 115 & 41.5 & & \\
\hline 3 ve üzeri & 13 & 10.9 & 21 & 13.3 & 34 & 12.3 & 27.8 & $<0.001$ \\
\hline Toplam & 119 & $42.9^{*}$ & 158 & $57.1^{*}$ & 277 & 100.0 & & \\
\hline
\end{tabular}

*Satır yüzdesidir, diğerleri sütun yüzdesidir. 
Araștırma sırasında akraba/tanıdık ihtiyacı nedeniyle kan verenler, katılımcıların \%57.0'ını oluşturmaktadır. Gönüllülük esasına göre yapılmayan kan bağışı tüm dünyada sorun teşkil etmektedir. $^{2}$ Yunanistan'da yapilan çalışmada replasman kan bağışçılarının büyük bir kısmının, bağışta bulunmak için akraba/tanıdıklarının kan bağıșına ihtiyacı olmasını beklediği rapor edilmiştir. ${ }^{9}$ Mersin'de Yıldız ve arkadaşlarının yaptığı çalışmada "kan ve kan ürünleri sizce hangi yollardan sağlanır?" sorusuna katılımcıların sadece \%37.2'si "Kızılay" yanıtını seçmiş; \%31.4'ü "hasta yakınlarından", \%29.2'si ise "gönüllülerden sağlanır" cevabını vermiştir. ${ }^{15}$ Sağlık açısından olumlu etkilerinin olduğunun düşünülmesi ve kan bağışının alışkanlık haline gelmesi çalışmamızda en sık görülen ikinci kan bağışlama nedenidir (\%22.7). Gönüllü olma durumuna göre değerlendirdiğimizde çalışmaya katılan 277 kişinin 119'unu gönüllüler oluşturmaktadır. Araştırmada gönüllü olma kriteri, şu anda bağışta bulunma nedeninin akraba/arkadaş ihtiyacı (kana kan bağışçısı) olarak belirtilmesi veya belirtilmemesidir. Gönüllü kan bağışçılarının \%89.9'u Kızılay kan merkezlerinde kan bağışında bulunmuştur. Üniversite hastanesinde ise kan bağışlayanların yalnızca \%7.4'ü gönüllüdür. İran'da 2012 yılında kan transfüzyon merkezinde yapılan bir çalışmada da bağıșta bulunanların \%85.6'sını başkalarına yardım duygusuyla kan veren gönüllü bağışçllar oluşturmuştur. $^{11}$ İtalya'da yapılan bir çalışmada adolesan yaş grubuna gönüllü kan bağışında bulunan kişinin duygusal olarak ne hissedebileceği sorulmuş; katılımclar hayat kurtaran, iyi ve faydalı bir eylem olduğu için kan bağışlayanın kendini yararlı, duygusal açıdan tatmin olmuş ve çevresi tarafından takdir edilen bir birey olarak hissedebileceği cevabını vermişlerdir. ${ }^{16}$
Bir başka çalışmada da kan bağıșı davranışı ile ilgili benzer sonuçlar yer almaktadır. ${ }^{10}$ Mersin'de yapılan çalışmada ise "kan bağıșlamanın ifadesi nedir?" diye sorulduğunda katılımcıların \%93'ü kan bağıșlamayı "vatandaşlık görevi" olarak tanımlamıştır, buna rağmen yeterli kan bağışında bulunmamaktadırlar. ${ }^{15}$

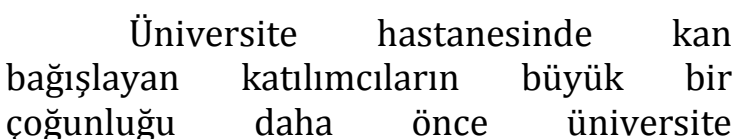
hastanesinde, Kızılay'da kan bağışlayanların büyük çoğunluğu da daha önce Kızılay kan bağışı merkezlerinde bağıșta bulunmuşlardır. Bağışçıların alıştıkları yollar aracılığı ile kan bağıșı davranışını devam ettirdiklerini söylemek mümkündür. En çok hastanelerde bağıșta bulunanların kan bağışı davranışlarını değiștirmek ve Kızılay kan bağışı merkezlerinde kan bağıșında bulunmalarını sağlamak gerekmektedir. Bunun için kan bağıșı merkezlerinin kan ihtiyacını karşılamada tek merkez olması gerektiğinin belirtilmesi önemlidir. Katılımcıların neredeyse tamamı "tekrar kan bağışında bulunur musunuz?" sorusuna "evet" cevabını vermiştir.

Gönüllü olmanın kan bağışı üzerine etkisine dair görüşleri katılımcılara sorulmuș ve bu soruyu hem üniversite hastanesinde hem de Kızılay'da bağıșta bulunanların çok büyük bir bölümü "önemlidir" veya "kesinlikle önemlidir" olarak cevaplandırmışlardır. $\mathrm{Bu}$ sonucun ortaya çlkmasında gönüllü kan bağışçısı tanımının kan bağışlayanlar tarafından doğru tanımlanamıyor olmasının payı büyüktür. Kan bağıșında bulunanlar para karşılığı bağışta bulunmanın dışındaki seçenekleri gönüllü kan bağıșı çerçevesinde ele almaktadır. Bu yanılgının düzeltilmesi şüphesiz gönüllü kan bağıșı sayısında artışa katkıda bulunacaktır. Akraba/tanıdıklarının kan ihtiyacı olması halinde bu durum bağıșta bulunma davranışlarını etkiler mi sorusunu da bağışçılar benzer şekilde 
cevaplandırmışlardır. Her iki merkeze bağıșta bulunanlar da yakınlarının kan ihtiyacı olmasının kan bağışı davranışını etkileyeceği görüşündedirler.

Güvenilir kan bağışçısı yetersizliği nedeni ile ülkemizde hastane kan merkezlerinin en yaygın bağışçı profilini kana kan bağışçıları oluşturmaktadır. ${ }^{4}$ Gönüllü olma durumu bu araștırmada sosyo-demografik özelliklere göre incelenmiştir. Gönüllü olmayanların \%84.8'i çalışırken, gönüllü olanların $\% 49.5^{\prime} \mathrm{i}$ çalıșmaktadır. Gönüllü olanların \%44.5'i 1825 yaș aralığında, \%37.8'i 26-45 yaș aralığında, \%17.6'sı ise 45 yaş üstündedir. Gönüllü olmayanların ise \%19'u 18-25 yaș aralığında, \%72.2'si 26-45 yaş aralığında, $\% 8.9$ 'u 45 yaş üstündedir. Gönüllü olan ve olmayan bağışçıları kendi içinde değerlendirdiğimizde gönüllü bağıșçıların $\% 60.5$ 'i üniversite/yüksekokul mezunuyken, gönüllü olmayanların sadece \%37.3'ü üniversite/yüksekokul mezunudur. Katılımcıların medeni durumlarına bakıldığında gönüllü olanların sadece \%38.7'si evliyken, gönüllü olmayanların \%74.7'si evlidir. Bu sonuçlar yaş, çalışma durumu, medeni durum, öğrenim durumu gibi sosyo-demografik faktörlerin kan bağışı gönüllülüğü üzerine etkisi olduğunu göstermektedir. Daha önce yapılmış olan bir çalışmada da benzer sonuçlar elde edilmiştir. ${ }^{10}$

Bu sonuçlardan yola çlkarak gönüllü kan bağışçılığının artırılabilmesi için halka bağışta bulunmanın bir insanlık görevi olduğunun benimsetilmesinin önemli olduğu düşünülmüştür. Toplumu kan bağıșında bulunmaya teșvik edebilmek için çeşitli çalışmalar yapılabilir. Bu bağlamda tanıtım çalışmaları, gezici ekip çalışmaları değerlidir. Son olarak sivil toplum örgütlerinin kan bağışı konusuna eğilmeleri için çalışmaların yapılabilmesi önemlidir.

\section{Teșekkür}

Araştırmanın yapıldığı kan merkezlerinin yöneticilerine ve araștırmaya katılan kan bağıșçllarına teșekkür ederiz.

\section{Kaynaklar}

1. T.C. Sağlık Bakanlığı Ulusal Kan ve Kan Ürünleri Rehberi. p. 165-166. http://www.kanver.net/ulusal_kan_rehberi. pdf. Erişim tarihi: 13/09/2012.

2. WHO, Media Centre, Blood safety and availability, June 2012, Fact sheet N 279. p.1.

3. Bağışçı kazanım programları. Ulusal Kan Merkezleri ve Transfüzyon Tibbı Kursu XIITemel Kurs Kitabı, 2009, Antalya. p. 31-4.

4.Ulusal Güvenli Kan Temini Programı, Kan Hizmet Yönetimi, Ocak 2007. sdb.meb.gov.tr/okulsagligi/kizilay/bilinc.pp s. Erişim tarihi: 13/09/2012.

5. Hablemitoğlu Ş, Özkan Y, Yıldırım F. Bir fedakarlık örneği olarak kan bağışı. Aile ve Toplum2010;5(20):67-77.

6. Mutlu B. Bağışçı seçimi ve seyahat. III. Ulusal Kan Merkezleri ve Transfüzyon Kongresi Kitabı, 24-28 Kasım 2010, Antalya. p. 50-52.

7. Türk Kizılayı İnternet Sitesi. http://www.kanver.net/index.php?id=2. Erişim tarihi: 13/09/2012.

8. Kızılay Kan Hizmetleri Genel Müdürlüğü, 2011 Faaliyet Kitabı. http://www.kanver.org/kan_2011.pdf.

Erişim tarihi: 13/09/2012.

9. Marantidou O, Loukopoulou L, Zervou E, et al. Factors that motivate and hinder blood donation in Greece. Transfus Med 2007;17(6):443-50. 
10. Abdel Gader AG, Osman AM, Al Gahtani $\mathrm{FH}$, Farghali MN, Ramadan AH, Al-Momen AK. Attitude to blood donation in Saudi Arabia. Asian J Transfus Sci 2011;5(2):1216.

11. Kasraian L, Maghsudlu M. Blood donors' attitudes towards incentives: influence on motivation to donate. Blood Transfus 2012;10(2):186-90.

12. Yaşar KK, Pehlivanoğlu F, Işik ME, et al. $\mathrm{Ne}$ Kadar Farkındayız? Kan Bağıșı Konusunda Doktor Anketi. Haseki Tip Bülteni 2011;49(2):56-61.

13. Godin G, Vézina-Im LA, Bélanger-Gravel A, Amireault S. Efficacy of interventions promoting blood donation: a systematic review. Transfus Med Rev 2012;26(3):224237.e6.
14. Eser B, Kurnaz F, Kaynar L, Yay M, Şıvgın $S$, Ünal A, Çetin M. Are university students a favorable target group for blood donation campaigns? Turk J Hematol 2010;27(4):275-28.

15. Yıldız Ç, Emekdaş G, Kanık A, et al. Why don't we donate blood. A general view of blood donation by people living in Mersin: A public survey. Turk J Infect 2006;20(1):4155.

16. Zito E, Alfieri S, Marconi M, Saturni V, Cremonesi G. Adolescents and blood donation: motivations, hurdles and possible recruitment strategies. Blood Transfus 2012;10(1):45-58. 